University of Nebraska - Lincoln

DigitalCommons@University of Nebraska - Lincoln

6-2002

\title{
Unexpected Ecological Effects of Distributing the Exotic Weevil, Larinus planus (F.), for the Biological Control of Canada Thistle
}

Svata M. Louda

University of Nebraska - Lincoln, slouda1@unl.edu

Charles W. O'Brien

Florida A \& M University, cobrien@famu.edu

Follow this and additional works at: https://digitalcommons.unl.edu/bioscilouda

Part of the Ecology and Evolutionary Biology Commons

Louda, Svata M. and O'Brien, Charles W., "Unexpected Ecological Effects of Distributing the Exotic Weevil, Larinus planus (F.), for the Biological Control of Canada Thistle" (2002). Svata M. Louda Publications. 28. https://digitalcommons.unl.edu/bioscilouda/28

This Article is brought to you for free and open access by the Papers in the Biological Sciences at DigitalCommons@University of Nebraska - Lincoln. It has been accepted for inclusion in Svata M. Louda Publications by an authorized administrator of DigitalCommons@University of Nebraska - Lincoln. 


\title{
Unexpected Ecological Effects of Distributing the Exotic Weevil, Larinus planus (F.), for the Biological Control of Canada Thistle
}

\author{
Svat́a M. Louda \\ School of Biological Sciences \\ University of Nebraska-Lincoln \\ Lincoln, NE 68588-0118, U.S.A., email slouda@unl.edu
}

\author{
Charles W. O'Brien \\ Center for Biological Control \\ Florida A \& M University \\ Tallahassee, FL 32307-4100, U.S.A.
}

\begin{abstract}
Rhinocyllus conicus, a weevil introduced for biological control of exotic weeds, has had major nontarget ecological effects on native thistles. Some practitioners have argued that this is an isolated case. We report, however, that another Eurasian weevil (Larinus planus), currently being distributed in North America for the control of Canada thistle (Cirsium arvense), is significantly reducing seed production by a native thistle (Tracy's thistle, Cirsium undulatum var. tracyi) in Colorado. In 1999 we discovered L. planus feeding in flower heads of Tracy's thistle near a 1992-1993 biocontrol release site. Of the heads collected, $74 \%$ had evidence of L. planus, and these heads produced only 1.1 viable seeds on average, compared with 45.9 in heads without this weevil. In 2000 we investigated whether L. planus feeding persisted on Tracy's thistle and whether this feeding affected seed production significantly. Feeding by L. planus occurred on $80 \%$ of the plants and in $76 \%$ of all the main heads of Tracy's thistle. Flower heads with L. planus averaged 1.4 viable seeds, compared with 44.5 in uninfested heads. Feeding by L. planus decreased the average number of viable seeds produced per plant by over $51 \%$. In contrast, L. planus had less effect on its targeted exotic host, Canada thistle than it did on Tracy's thistle. The high-frequency and high-level feeding of L. planus on the native species, coupled with the lack of evidence of its effectively limiting the seed production or density of Canada thistle suggest that the deliberate distribution of this weevil entails a high risk-to-benefit ratio and should be discontinued. Our findings challenge the general assumption that biological control with exotic insects is consistent with conservation goals of weed management in natural areas. Effective, a priori quantitative evaluation of the potential effects on both target and nontarget species and better regulatory oversight are required.
\end{abstract}

\section{Resumen}

Efectos Ecológicos Inesperados de la Distribución del Gorgojo Exótico, Larinus planus (F.), para el Control Biológico del Cardo de Canadá: Rhinocyllus conicus, un gorgojo introducido para el control de hierbas exóticas, ha tenido importantes efectos ecológicos en cardos nativos. Sin embargo, algunos profesionales han argumentado que este es un caso aislado. Reportamos que otro gorgojo eurasiático (Larinus planus), que actualmente está siendo distribuido en Norte América para el control del Cardo de Canadá (Cirsium arvense), esta reduciendo significativamente la producción de semillas de un cardo nativo (Cirsium undulatum var. tracyi) en Colorado. En 1999 descubrimos a L. planus alimentándose de flores de C. undulatum cerca de un sitio de liberación de biocontrol en 1992-1993. De las flores recolectadas, el $74 \%$ tenía evidencia de L. planus y estas flores produjeron solo 1.1 semillas viables en promedio, en comparcaión con 45.9 en flores sin este gorgojo. En 2000 investigamos si persistía la alimentación de L. planus en el cardo nativo y si esto afectaba la producción de semillas significativamente. El forrajeo de L. planus ocurrió en el $80 \%$ de las plantas y en el 76\% de las flores del cardo nativo. Las flores con L. planus promediaron 1.4 semillas viables, comparadas con 44.5 en flores no infestadas. El forrajeo de L. planus disminuyó el número promedio de semillas viables producidas por planta en más del 51\%. En contraste, L. planus tuvo menor efecto en su hospedero exótico, C. arvense, que en el cardo nativo. La alta frecuencia y nivel de L. planus alimentándose de la especie nativa, aunado a la falta de evidencia de algún efecto sobre la producción de semillas o la densidad de $C$. arvense, sugieren que la distri- 
bución deliberada de este cardo conlleva una alta proporción de riesgo a beneficio y debe descontinuarse. Nuestros resultados desafían la suposición general de que el control biológico con insectos exóticos es consistente con las metas de conservación del manejo de arbustos en áreas naturales. Se requieren evaluaciones cuantitativas efectivas, a priori, de los efectos potenciales tanto en especies blanco como no blanco, así como mayor vigilancia.

\section{Introduction}

Invasive weeds represent a significant challenge in natural-area management (Office of Technology Assessment 1993; Randall 1993; National Invasive Species Council 2000). Biological control has been assumed to be an effective, environmentally safe strategy for weed management in natural areas (e.g., Malecki \& Blossey 1994; Van Driesche 1994; Center et al. 1995; Office of Technology Assessment 1995; Delfosse 2000 . Although there is strong evidence now that this strategy can have unanticipated ecological consequences (Follett \& Duan 2000; Wajnberg et al. 2001, a controversy persists over the frequency and magnitude of ecological side effects in biological control.

The evidence on Rhinocyllus conicus (Frölich), a Eurasian flower-head weevil deliberately introduced to control Carduus spp. such as musk and nodding thistles, shows that the insect's diet breadth includes at least 22 native North American taxa (Rees 1977; Goeden \& Ricker 1986a, 1986b, 1987a, 1987b; Turner et al. 1987; Louda et al. 1997; Herr 2000; Pemberton 2000). In addition, the destruction of flower heads and seed by R. conicus is severe for some native species (Turner et al. 1987; Louda et al. 1997, 1998; Louda \& Arnett 2000). The availability of both experimental and demographic data on Platte thistle (Cirsium canescens Nutt.) in sand-prairie preserves prior to $R$. conicus expanding its host range onto it (Louda et al. 1990, 1992; Louda \& Potvin 1995) has allowed a quantitative assessment of the fitness and population consequences of this expansion (Louda et al. 1997, 1998; Louda 1998b; Louda \& Arnett 2000). The seed loss superimposed by $R$. conicus over and above that of the native inflorescence feeders has been significant, suggesting that both the lifetime fitness and local plant density of this native species are being affected severely (Louda 1999; Louda \& Arnett 2000).

Advocates of biocontrol have argued, however, that this case represents an exception (Boldt 1997; Delfosse 2000). If so, then the evidence, although disturbing, would not suggest a need to improve contemporary practices. Alternately, the findings could indicate that a problem exists, that current practices are not yet adequate to protect the native flora (Simberloff \& Stiling 1996; Louda 1998a, 2000; Louda et al. 1998; Stiling \& Simberloff 2000; Strong \& Pemberton 2000. Few data are available with which to evaluate these alternatives because post-release quantitative assessments of the outcomes and potential side effects of biological control are rare (Simberloff \& Stiling 1996).
This study began in an effort to expand the data on use by R. conicus of Cirsium species. We sampled insects and damage to flower heads of Tracy's thistle, Cirsium undulatum (Nutt.) Spreng. var. tracyi (Rydb.) Welsh, a native species of western Colorado and eastern Utah (Kartesz 1998). Instead of R. conicus, we found another Eurasian weevil, Larinus planus (Fabricius), feeding on the flower heads. This species of Larinus is currently being distributed in the United States and Canada for the biological control of another Eurasian thistle, Cirsium arvense L. (Canada thistle). Our initial data in 1999 documented the unexpectedly high occurrence of feeding and the successful development of L. planus within the flower heads of this large-flowered thistle native to North America. In 2000 we sampled more intensively to determine the extent to which L. planus reduced seed production by Tracy's thistle and Canada thistle.

Specifically, our aims were to determine (1) if feeding by L. planus on Tracy's thistle inflorescences persisted for a second year, (2) whether L. planus was restricted to the stand where it was first discovered, (3) whether feeding by L. planus reduced a plant's seed production significantly, and (4) how the effect of L. planus on seed production of Tracy's thistle compared to the weevil's effect on its targeted weed, Canada thistle. Evidence that $L$. planus is causing a serious reduction in the number of seeds produced by a native North American Cirsium species, such as Tracy's thistle, would contradict the prediction, based on a contemporary evaluation of host specificity, that L. planus is not likely to harm North American thistle populations (McClay 1990).

\section{Taxonomy and Natural History of Larinus}

The genus Larinus Germar 1824 is a Palearctic genus of 150-200 species (Hoffmann 1954). Host radiation in Larinus has been confined to the thistle tribe Cardueae (= Cynareae) of the Asteraceae (Zwölfer et al. 1971; Zwölfer \& Harris 1984; McClay 1990). The species L. planus (Fabricius) (Coleoptera: Curculionidae) was previously referred to as L. carlinae (Olivier) (e.g., Zwölfer 1964; Zwölfer et al. 1971 in the subfamily Cleoninae (Hoffmann 1954), tribe Lixini (O'Brien \& Wibmer 1982; Zwölfer \& Harris 1984). It is now in the subfamily Lixinae, tribe Lixini (Alonso-Zarazaga \& Lyal 1999).

Adults of L. planus, a univoltine species, are about $7-8 \mathrm{~mm}$ long and $3 \mathrm{~mm}$ wide, and newly emerged individuals are covered with a yellowish, waxy coating on grayish pubescence (Zwölfer 1964; White 1972). The 
rostrum on females is elongated and curved (1.0-1.6 $\mathrm{mm}, 16.8 \%$ of total female length: Zwölfer 1964 . To oviposit, the female chews a tunnel into the interior of the flower head near its base, inserts eggs into the tunnel, and then plugs the tunnel with masticated plant and fecal material (Zwölfer et al. 1971; Wheeler \& Whitehead 1985). The larvae develop within the flower heads (capitula), destroying the majority of the florets, developing seeds, and receptacle tissues (Zwölfer 1964; Zwölfer et al. 1971; Wheeler \& Whitehead 1985). Pupation takes place within the feeding chamber. Adults emerge in late summer and overwinter.

Host-plant records for L. planus from its indigenous region include a wide array of species in the Cardueae (Zwölfer 1964; Zwölfer et al. 1971), especially the subtribe Carduinae (true thistles) but also in Centaureinae (knapweeds). In the eastern portion of its distribution (Ukraine and east) recorded host plants include Cirsium setosum, C. incanum, Carduus thoermeri, and species of Carlina, Serratula, Centaurea, and Chrysanthemum (Volovnik 1996). In the western portion of its range (Europe), multiple thistle genera are hosts, including Carduncellus, Carduus, Carlina, Carthamus, Centaurea, Cirsium, Cynara, Echinops, and Onopordum (Hoffmann 1954). Field records in Europe suggest that "L. carlinae oviposits into Cirsium spp. with small flower-heads," especially Canada thistle (Zwölfer 1964).

\section{Evaluation of Larinus planus for Biological Control}

Six species of Larinus were screened in the 1960s as potential biological control agents (Zwölfer 1964; Zwölfer et al. 1971). All six European Cirsium species offered to L.(carlinae) planus received "regular and spontaneous feeding ... [at] comparatively high levels" (Zwölfer 1964). No North American native species of Cirsium were tested. As a result of this host-specificity testing, Zwölfer (1964) concluded that "All these [weevil] species reach their highest [preference] indices on members of the Carduinae ... Here Rh[inocyllus]conicus is more restricted than the other [Larinus] species." Thus, no official introductions of L. planus were made into North America.

However, L. planus became established in the United States in the 1960s. The first published observation was made on June 15, 1971 (White 1972). This individual came from "Cirsium sp." in a field in Maugansville, Maryland, in which a European flea beetle (Chrysomelidae: Altica carduorum Guerin-Meneville) had been released for control of Canada thistle. Two earlier records were subsequently found in collections: August 1968 near Dover, Ohio, and April 1969 near Taughannock Falls, New York (Wheeler \& Whitehead 1985). Wheeler and Whitehead (1985) found that L. planus was established in northern Maryland and Pennsylvania and in isolated locations of eastern Ohio and central New York. They suggested that because L. planus was established in the United States, it should "be studied for possible release in other areas of North America where Canada thistle is a pest."

Following up on this suggestion, McClay (1990) used contemporary protocols to evaluate the host specificity of L. planus as a prerequisite to its release in Canada. Host-specificity tests included both adult preference and larval performance on potential host-plant species. Tests of adult feeding preference involved both no-choice and choice tests among leaves presented in petri dishes. These tests included five North American Cirsium species: C. andrewsii (Gray) Jep.; C. flodmanii (Rydb.) Arthur; C. foliosus (Hook.) D.C.; C. hookerianum Nutt.; and C. undulatum (Nutt.) Spreng. McClay (1990) found patterns in feeding by L. planus suggesting that it prefers Canada thistle over the native North American species, but he did not test the differences observed. When we calculated $95 \%$ confidence intervals for the means given by McClay (1990 [his Table 1]), we found that in all nine no-choice tests and in seven out of eight choice tests, the average amount of feeding by L. planus on native thistles was not significantly less than that on Canada thistle. Only leaves of $C$. flodmanii received less feeding by $L$. planus in choice tests with Canada thistle.

Using potted plants in screened cages, McClay tested the oviposition preferences and larval development of L. planus. These tests included three of the native North American species as potential hosts: Cirsium flodmanii, C. undulatum, and C. drummondii Torrey \& Gray (McClay 1990). C. drummondii received no ovipositions, but the sample size was small (a total of 4 female-days). $C$. flodmanii and C. undulatum evaluated with larger sample sizes, were accepted as oviposition hosts and both supported complete development, but there was no emergence of L. planus adults (McClay 1990).

Thus, the contemporary screening tests showed that L. planus might prefer the alien Canada thistle but that it would feed, oviposit, and likely develop on several North American natives. But because L. planus adults were thought to prefer the targeted exotic species and because their larvae developed more successfully on the exotic species than on the accepted native species, McClay (1990) concluded that Larinus planus was "unlikely to form significant populations on them [native North American thistles]." He suggested that "the redistribution of L. planus to Alberta, and other areas of North America where $C$. arvense is a problem, should be considered" (McClay 1990).

Since 1990, L. planus, which is available commercially by mail and via the Internet, has been released in British Columbia (IPMnet News 1995), and it is being redistributed from the northeast into other ecoregions of the United States. For example, we found records for nine official releases of L. planus in Colorado for control of Canada thistle since 1991 (6,962 weevils at 26 sites) (Ta- 
Table 1. Reported official releases of Larinus planus in Colorado, 1991-1999.

\begin{tabular}{|c|c|c|c|c|c|}
\hline Location & Year & $\begin{array}{l}\text { Number } \\
\text { released }\end{array}$ & Sites & Agency & Source* \\
\hline \multicolumn{6}{|l|}{ El Paso County } \\
\hline Fort Carson, ARA site & 1997 & 47 & 1 & U.S. Army & 1 \\
\hline Fort Carson, ARA site & 1998 & 150 & 1 & U.S. Army & 1 \\
\hline Fort Carson, gate 5 contonment & 1998 & 400 & 1 & U.S. Army & 1 \\
\hline \multicolumn{6}{|l|}{ Gunnison County } \\
\hline Somerset at Paonia Reservoir & 1997 & 65 & 1 & Colorado Department of Agriculture & 3,4 \\
\hline Jefferson County & 1993 & 400 & 2 & County Noxious Weed Department & 4 \\
\hline Jefferson County & 1994 & 1200 & 4 & County Noxious Weed Department & 4 \\
\hline \multicolumn{6}{|l|}{ Montezuma County } \\
\hline \multicolumn{6}{|l|}{ Mesa Verde National Park, Far View } \\
\hline Lagoon area & 1998 & 4200 & 14 & National Park Service & 5 \\
\hline
\end{tabular}

* Sources: 1) D. Fritts and J. Michels, Entomology Department, Texas A \& M University, personal communication; 2) U.S. Forest Service, Taylor River Ranger District, memo on biological control of weeds, November 16, 1993; 3) K. Mowrer, Colorado Department of Agriculture, personal communication; 4) National Agricultural Pest Information System, U.S. Cooperative Agricultural Pest Survey, Releases of L. planus on Canada thistle, 1990-1999: (Wyoming Cooperative Agricultural Pest Program, Laramie. Online at http://www.ceris.purdue.edu [accessed April 11, 2001]); 5) Mesa Verde National Park, Burned area Emergency Rehabilitation Report, 1998 (online at http://www.nps.gov/meve/mvnp/pages/ baer.htm [accessed November 3, 1999]).

ble 1), which included release by federal agencies (U.S. Army, U.S. Forest Service, and National Park Service) on federal lands (Fort Carson, Gunnison National Forest, Mesa Verde National Park). Yet Colorado has at least 17 native Cirsium species (Harrington 1964), with 16 species currently listed on the western slope of the Rocky Mountains in Colorado (Weber 1987). The Colorado Natural Heritage Program considers two of the western species to be rare and sensitive (Cirsium ownbeyi Welsh, C. perplexans [Rydb.] Petrak), but this exotic weevil was released for biological control into native vegetation on federal lands without an evaluation of its potential effects on these species. In the context of the current controversy, it is important to note that these releases occurred after the enactment of both the National Environmental Policy Act of 1969 and the Endangered Species Act of 1972. These laws technically restrict federal actions that could affect the environment or further reduce populations of rare species.

Other Great Plains and western states are also distributing L. planus in efforts to control Canada thistle. For example, releases of L. planus were made in six counties in Nebraska by the U.S. Department of Agriculture's Animal and Plant Health Inspection Service and the state's Forestry Department (6,602 weevils; 1996-1998); in three counties in South Dakota, including Wind Cave National Park, Badlands National Park, Buffalo Gap National Grassland, and Black Hills National Forest, by the National Park Service and the U.S. Forest Service $(2,100$ weevils; 1991-1998); 14 counties in Wyoming, including Fossil Butte National Monument, by county Noxious Weed Departments and the National Park Service (17,465 weevils; 1992-1999); in two counties in Idaho by the U.S. Forest Service (2,000 weevils; 1993-1994); and in
13 counties in Oregon by the state Agriculture Department (3,000 weevils; 1997-1999) (Zimmerman 1997; Rice \& Roddy 1998; Anonymous 1999; National Park Service 1999; Cooperative Agricultural Pest Survey 2001). Thus, the distribution of this weevil to Colorado is not an isolated occurrence.

\section{Methods}

We began our study in 1999 by sampling 30 flower heads of Tracy's thistle in a roadside stand along State Highway 135 on the edge of the Gunnison National Forest near the town of Almont in central Colorado $(1.6 \mathrm{~km}$ southwest of Almont, $15.7 \mathrm{~km}$ north of Gunnison). This stand had been sampled previously in 1989. Our purpose was to determine if Rhinocyllus conicus was using native species on the western slope of the Rocky Mountains, as it was on the eastern slope (Louda et al. 1997), but we found L. planus instead. According to information obtained subsequently, official releases of L. planus by the U.S. Forest Service had been made $0.3 \mathrm{~km}$ northeast of this stand in 1992 and 1993 (Table 1).

On July 24, 1999, 30 flower heads (capitula) terminal on branches were chosen arbitrarily and collected. Ten heads were examined immediately for evidence of insect feeding, and 20 were returned to the laboratory at the University of Nebraska and dissected on August 3, 1999. For the heads dissected, the type and amount of insect feeding were recorded and the insects were preserved. These insects included two adults that had emerged successfully between collection and dissection. Within a month, the junior author determined the identity of the weevils reared from this sample. 
On July 24-25, 2000, we revisited the same stand sampled in 1999 and took more intensive data. In addition, we found a second stand of Tracy's thistle $1.9 \mathrm{~km}$ northeast of the first stand, $0.3 \mathrm{~km}$ east of Almont along the Taylor Reservoir Road. The second site was $1.6 \mathrm{~km}$ northeast of the 1992-1993 release site. Comparable data were taken for this second stand on July 26-27, 2000.

For each stand, we recorded the density of flowering plants by measuring habitat area and counting the number of bolting plants. In each stand, $62 \%$ of the flowering plants were chosen randomly for measurement of plant performance $(n=10$ out of 16 plants in stand 1 and 5 out of 8 plants in stand 2). For each plant, we recorded plant height, reproductive effort, flowering success, and amount of floral herbivory by insects. Reproductive effort was measured as the total number of flower heads ( $>4 \mathrm{~mm}$ diameter) initiated per ramet and per plant. We measured flowering success as the total number of heads that flowered (exerted at least one floret) per flowering branch (ramet) and per plant. Insect floral herbivory was recorded as the total number of heads damaged by insect feeding and the number of heads with unambiguous external evidence of feeding by L. planus per ramet and per plant. Damaged heads were defined as those that had $>5 \%$ of the external area of the phyllaries with evidence of chewing damage or browning associated with insect feeding.

We also measured flower-head development and seed production per plant by dissecting all the flower heads on every other plant sampled in stand $1(n=5$ plants, 185 heads) and flower-head development on all of the plants sampled in stand 2 ( $n=5$ plants, 166 heads). In stand 1 , for each flower-head we recorded diameter, flower-head development (small bud to flowered and matured), number of florets initiated (if countable), number of viable seeds, damage score for insect feeding (0-6), and number of insects present. The score for insect-feeding damage was based on external evidence of insect-feeding intensity on flower heads: 0 , none; 1 , slight $(<1 \%$ area); 2 , small (1-5\% area); 3, medium (5-25\%); 4 , severe ( $>25 \%$ area); 5 , stem mining within $1 \mathrm{~cm}$ of flower head; 6 , hole bored through phyllaries of the head (Bevill et al. 1999). In stand 2 , for each head we recorded number of viable seeds, presence or absence of weevil-feeding damage, and number of insects present. The total numbers of seeds initiated and damaged per ramet and per plant were calculated as the product of the average number of florets initiated per head by Tracy's thistle from stand 1 (66.0, SE 3.21), the average number of heads per flowering branch (ramet), and the number of flowering branches (ramets) per plant.

Similar data were collected from three stands of Canada thistle ( $n=5$ ramets per stand; reproduction by rhizomes makes plants [genets] difficult to distinguish). Two stands were $0.1 \mathrm{~km}$ from the documented release site for L. planus, and one stand occurred along Colorado State Highway 50, west of the Blue Mesa Reservoir,
$12.8 \mathrm{~km}$ west of Gunnison and about $22 \mathrm{~km}$ directly to the southwest of the release site near Almont.

\section{Results}

\section{Insect Identity}

We identified the weevils that developed and emerged from the flower heads of Tracy's thistle by examining them and comparing them with known specimens. The weevils were L. planus (F.). These determinations were done by $\mathrm{C}$. W. O., a curculionid specialist (e.g., O'Brien \& Wibmer 1982. Comparison was made with authoritatively identified specimens from Europe and from Colorado, Maryland, New York, Oregon, and Pennsylvania. In addition, comparison was made with other European Larinus species introduced as biological control agents: L. curtus Hochhut, L. minutus Gyllenhal, and L. obtusus Gyllenhal (Julien \& Griffiths 1998). The specimens were added to the $\mathrm{O}^{\prime}$ Brien weevil collection at Florida A \& M University, Tallahassee.

\section{Use of Tracy's Thistle by Larinus planus}

Eight of the 10 flower heads (80\%) of Tracy's thistle opened in the field in 1999 had evidence of insect feeding. This included chewed pappi compacted into soft pupal chambers, but no evidence of egg cases, entry tunnels, or hard black pupal chambers characteristic of $R$. conicus occurrence. Fifteen of the 20 heads (75\%) of Tracy's thistle dissected in the laboratory also contained unambiguous evidence of oviposition, successful development, and emergence by L. planus. Weevils at three stages of development (larvae, pupae, new adults) were found within the heads, and $33 \%$ of the adult weevils found had emerged unaided into the collection bags.

The level of feeding by weevils within the attacked main heads was high and associated with characteristic damage. Eight of the dissected heads (40\%) contained either pupae or new weevil adults. The damage associated with these weevils included holes bored into the receptacle, a soft chamber packed with chewed capillary pappus hairs, and frass (excreted pellets). Seven additional flower heads (35\%) had the same type and quantity of damage as the flower heads that had weevils, including pupation chambers from which the adults had emerged. Flower heads with evidence of feeding by $L$. planus averaged only 1.1 (SE 0.62) viable seeds per head, compared with 45.9 in all other flower heads.

The five remaining flower heads had varying evidence of feeding by insects. Three heads had an unknown tephritid fly larva, and the damage associated with flies included mealy, crumbly receptacles; clumps of seeds or florets; and dull, dark, flat, aborted, undeveloped 


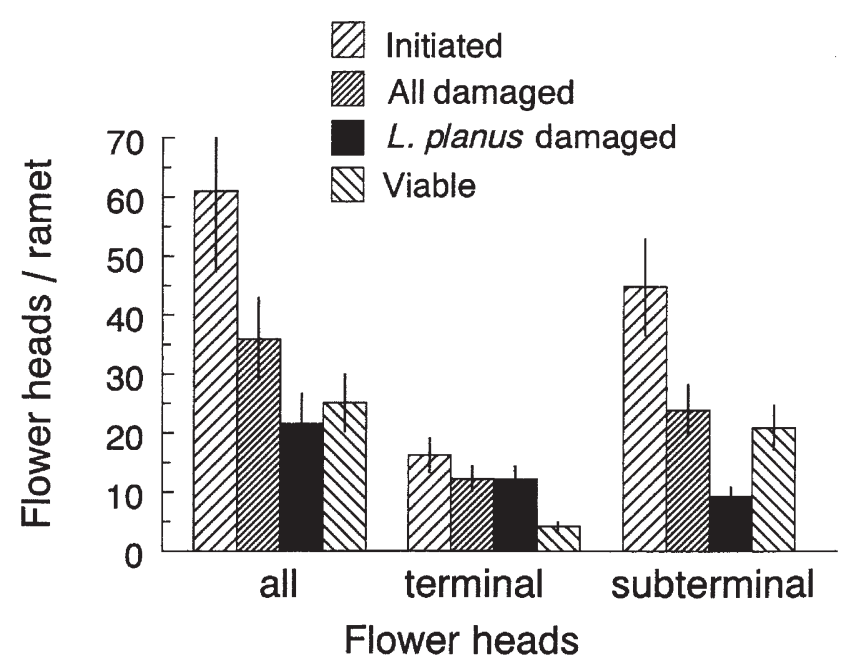

Figure 1. Average number of all flower heads, main plus branch terminal flower heads, and branch subterminal flower heads per plant for Tracy's thistle (Cirsium undulatum (Nutt.) Spreng. var. tracyi (Rydb.) Welsh) in stand 1 near Almont, Colorado, in late July 2000. Bars represent the mean flower heads $( \pm S E)$ that were initiated, damaged by feeding of all insects, damaged by Larinus planus (F.) specifically, and not damaged by insects. Only the latter produced significant numbers of viable seeds.

seeds. Flower heads with fly damage averaged significantly more viable seeds than those with $L$. planus damage: 8.7 (SE 7.2) per head $(p<0.01$, Mann-Whitney U test). Finally, two heads contained only frass, seeds with holes chewed in them near the junction of the achene with the pappus, and no feeding damage to the receptacle. Larvae of native pyralid moths (e.g., Homeosoma impressale Hülst) cause similar damage in other Cirsium spp. in the upper Great Plains (S. M. L., unpublished data).

The follow-up data collected in 2000 were more detailed, and they were collected at both the original stand located $0.3 \mathrm{~km}$ west of the Larinus planus release site and a second stand of Tracy's thistle located $1.6 \mathrm{~km}$ northeast of the same L. planus release site. The density of Tracy's thistle in the original stand was 1.8 flowering plants per $100 \mathrm{~m}^{2}(60 \times 15 \mathrm{~m}$ area $)$. These plants had 1.7 flowering branches (ramets) on average (SE 0.51), making flowering ramet density 3.1 per 100 $\mathrm{m}^{2}$. Ramets averaged $75 \mathrm{~cm}$ tall (SE 5.00). Each ramet initiated 61.0 heads (SE 13.8) on average, of which 16.2 (SE 3.38) were terminal heads on branches. Such heads typically produce the majority of viable seeds (Louda \& Potvin 1995). No Canada thistle was visible at either site.

Insect feeding on and damage to the main terminal head and to the axillary heads that were terminal on the main side branches (= terminals here, too) was heavy (Figure 1). On average $74.1 \%$, (SE 3.00) of these termi-

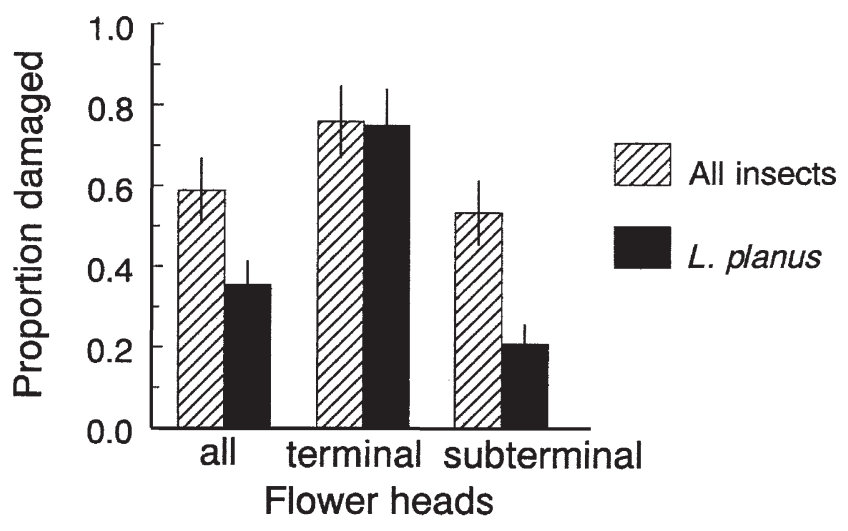

Figure 2. Proportion of all heads, main plus branch terminal heads, and branch subterminal heads per plant of Tracy's thistle (Cirsium undulatum var. tracyi) damaged by all insects and by Larinus planus specifically in two stands near Almont, Colorado, in late July 2000.

nal heads had unambiguous external evidence of insect feeding, similar to the 75\% observed in 1999. Dissection of flower heads revealed that $76.2 \%$ of the terminal flower heads $(n=75)$ had been fed upon by L. planus. These heads contained either a weevil or distinctive evidence of its feeding. In addition, an average of 35.9 (SE 7.13) of the smaller subsidiary axillary heads (58.5\%) under terminal heads on the side branches showed evidence of insect feeding. Among these subsidiary heads, L. planus had damaged 21.6 heads (SE 5.14) on average, accounting for $60.2 \%$ of the insect damage recorded on subsidiary heads (Figure 2).

Seed production by Tracy's thistle was decreased severely by L. planus. Flower heads with L. planus averaged 1.4 (SE 0.40) viable seeds, significantly fewer than the 44.5 (SE 2.98) viable seeds for all heads without the weevil $(t=14.94, p<0.001)$. Feeding by insects also reduced by $67 \%$ on average the total production of seeds matured by a plant. More than half of this seed loss (51.3\%, SE 4.53) was directly attributable to feeding by L. planus (Figure 3).

Results from the second stand were similar to those from the first. In a $60 \times 10 \mathrm{~m}$ moderately disturbed roadside of the Gunnison National Forest, the density of Tracy's thistle was 1.7 flowering plants, each with 2.5 flowering ramets, for a density of 4.3 ramets per 100 $\mathrm{m}^{2}$. Tracy's thistle here averaged $72 \mathrm{~cm}$ tall (SE 6.92), with 12.0 terminal heads (SE 2.02) and 33.2 total heads (SE 6.97) per ramet. On average, 9.4 (SE 1.68) of the 12.0 terminals $(78.3 \%)$ had external evidence of insect feeding. Total seed production of all terminal heads (main + branch terminals) was reduced $98 \%$, to 1.3 viable seeds per head. Total seed production was reduced $59 \%$ by L. planus feeding, similar to the $67 \%$ loss observed at site 1 (Figure 1). No Canada thistle was visible at the site. 


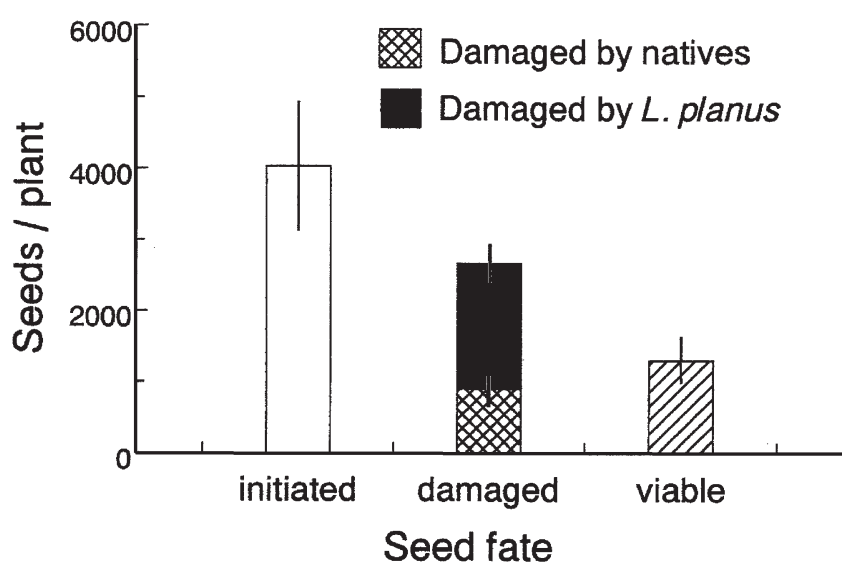

Figure 3. Seed reproductive effort and seed fate of Tracy's thistle (Cirsium undulatum var. tracyi) in stand 1 in the Gunnison National Forest near Almont, Colorado, in late July 2000, with number of seeds eliminated by feeding of native insects, number eliminated by Larinus planus specifically, and the number of potentially viable seeds remaining to be dispersed per plant.

\section{Use of Canada Thistle by Larinus planus}

Feeding by L. planus on the inflorescences of the targeted exotic Canada thistle was much lower than on the inflorescences of the native Tracy's thistle in the Gunnison Basin, even though two of the Canada thistle stands were $<0.1 \mathrm{~km}$ from the original release site and between the two Tracy's thistle sites. At the first Canada thistle stand, plant density was 119 ramets per $100 \mathrm{~m}^{2}$ in a $3 \times 7 \mathrm{~m}$ roadside area. Although vegetative reproduction by Canada thistle rhizomes makes perplant estimates difficult, per-ramet data can be compared with that for Tracy's thistle. Ramet height for Canada thistle averaged $72.2 \mathrm{~cm}$ (SE 3.84), and ramets initiated 43.0 flower heads (SE 4.64) per ramet. On average, $5.2 \%$ of those heads $(n=215)$ had evidence of insect-feeding damage. None of them, however, had any internal evidence of feeding and development by L. planus.

At $50 \mathrm{~m}$ from the first stand and $<0.1 \mathrm{~km}$ from the original release site, we found another small stand of three ramets of Canada thistle. Their height averaged $36.7 \mathrm{~cm}$ (SE 4.63), and the flower heads initiated averaged 7.7 (SE 0.88) per ramet. No insect damage to the heads on these ramets $(n=23)$ was recorded.

In the third stand of Canada thistle, $12.8 \mathrm{~km}$ west of Gunnison on Highway 50 and about $22 \mathrm{~km}$ by air from the release site, ramet density was 45 ramets per $100 \mathrm{~m}^{2}$ in a $10 \times 40 \mathrm{~m}$ roadside area. Ramet height averaged $53.4 \mathrm{~cm}$ (SE 6.01), with 27.4 heads per ramet (SE 6.87). In this stand, $32.8 \%$ of the heads $(n=137)$ had evidence of insect feeding damage. Dissection of the Canada thistle heads with external evidence of insect feeding revealed fly larvae but no use by L. planus.

\section{Discussion}

\section{Effect of Larinus planus on Tracy's Thistle}

The U.S. Army, U.S. Forest Service, National Park Service, and Colorado Department of Agriculture's Biological Pest Control Section have active biological control programs against Canada thistle (Cirsium arvense) on public lands in Colorado (Table 1). These programs have released three exotic insects: Ceutorhynchus litura (F.), Urophora cardui (L)., and L. planus (National Park Service 1999; Cooperative Agricultural Pest Survey 2001). The evidence we present suggests that L. planus, deliberately released by the U.S. Forest Service in the Gunnison National Forest as part of this biological control effort, is having a significant negative effect near the release sites on the seed production of Tracy's thistle, a sparsely distributed native North American species restricted to western Colorado and eastern Utah.

For example, between $74 \%$ and $100 \%$ of all the terminal flower heads on individual flowering plants of Tracy's thistle in the two stands were heavily damaged by L. planus near a site at which the weevil had been released 7 and 8 years earlier. Feeding by L. planus larvae reduced the production of viable seed in terminal flower heads by $87.4 \%$ in 1999 and by $98-99 \%$ in 2000 . Overall insect destruction of seed, half $(51 \%)$ of which was directly attributable to this exotic weevil, reduced seed production per plant by $67 \%$.

For another thistle species on which we have extensive long-term data-Platte thistle (Cirsium canescens Nutt.) - seedling recruitment, lifetime plant fitness, and local density were all directly proportional to the number of viable seeds after insect feeding (Louda et al. 1990, 1992; Louda \& Potvin 1995). If the dynamics of Tracy's thistle are similar to those of the Platte thistle, then the demographic consequences of doubling seed loss in already sparse stands ( 1.7 flowering plants per $100 \mathrm{~m}^{2}$ ) of this short-lived perennial thistle are likely to be serious.

Furthermore, our estimate of the reduction in a plant's seed production directly caused by L. planus is likely to be conservative. In our calculations we made no adjustment for the probability of flowering success by head position and phenology. Most of the undamaged flower heads were the smaller, later, subsidiary heads that are subterminals on side branches (e.g., $38 \%$ subterminals vs. $76 \%$ terminals were damaged in stand 1 in 2000). Subterminal flower heads generally initiate fewer florets on average than the terminals (Straw 1989; Louda \& Potvin 1995). In addition, the majority of undamaged heads flowered late. Late inflorescences, especially those in subsidiary positions on branches, generally have much lower pollination and maturation success than do the terminal flower heads (e.g., Straw 1989; Louda \& Potvin 1995). By blocking seed production by the terminal flower heads, which would be expected to 
produce the bulk of the viable seeds, L. planus will have an even larger effect on seed production than suggested by our calculations.

In sum, we conclude that the total reduction in viable seed by L. planus will reduce the potential for recruitment and will likely lead to a quantitative decrease in the density and persistence of this native species in these stands over time. More information will have to be gathered, however, to predict an expected rate of decline for this species. The exact relationship of seed availability to plant population dynamics is not quantified. Also, the eventual magnitude of population buildup and the rate of spread of L. planus onto Tracy's thistle habitat in Colorado and Utah are unknown. One would need to learn the rate of spread of L. planus, both natural (unassisted) and deliberate, before one could calculate the long-term consequences for Tracy's thistle throughout its range in Colorado and Utah.

\section{Redistribution of Larinus planus}

The deliberate releases of L. planus into new ecoregions of the United States for the biological control of Canada thistle appear to reflect five interacting factors: (1) fear that Canada thistle will spread and dominate rangelands in North America, (2) an assumption that $L$. planus will help limit this spread, (3) inadvertent establishment of L. planus in the northeastern United States, (4) availability of at least one contemporary evaluation of host specificity, and (5) previous lack of information on potential ecological side effects on native North American thistles in the field.

First, Canada thistle does represent a threat to some rangeland, given evidence from other areas. For example, it has established and spread invasively in various places in the southern hemisphere (Amor 1975), and crop losses can be severe (Bailey et al. 2000). Consequently, its spread is feared (Moore 1975; Donald 1994), stimulating the search for methods of long-term control (Haber 1997; Bailey et al. 2000).

Second, however, we found no quantitative studies of the effectiveness of this weevil in limiting the density or the spread of Canada thistle. Thus, the inference that $L$. planus can contribute significantly to the control of Canada thistle is an untested assumption. We found that L. planus had no effect on seed production of Canada thistle where it was released in the Gunnison Basin of Colorado. Furthermore, there is no clear evidence that insect reduction of seed will contribute to substantially lower population density and persistence of the vegetatively reproducing Canada thistle (e.g., Forsyth \& Watson 1985; Wheeler \& Whitehead 1985). Evidence suggesting that an agent (L. planus) can reduce weed density (Canada thistle) should be necessary to justify the inherent risk associated with the deliberate movement of an exotic species into new areas (Harris \& McE- voy 1995; McEvoy 1996; Louda et al. 1998; Louda 1998a, 1999, 2000). No such evidence exists, and our data contradict this expectation directly. Yet, in the last 10 years L. planus has been redistributed in Canada and to at least five western states in the United States through Canada thistle control projects. In the United States, the redistribution is being done by both federal agencies and state governments, even subsequent to the National Environmental Policy Act and the Endangered Species Act and even in the light of contemporary evidence that the weevil's host range includes that of the native North American Cirsium spp. (McClay 1990).

Third, the inadvertent establishment of L. planus in one ecoregion is not a scientifically sound basis for its distribution to other ecosystems in North America. This seems evident in this case, especially because both Zwölfer and colleagues (1971) and McClay (1990) found that L. planus would feed, oviposit, and develop on multiple Cirsium species. In Colorado, L. planus halved the number of viable seeds produced by Tracy's thistle plants, and it used the native species more intensively than the targeted exotic species.

Thus, this case suggests that even accidental introductions need to be evaluated before redistribution. One possibility is to use the same process that is used for deliberate introductions because the infrastructure is already in place. This process entails submission of a detailed petition for movement and release to the Technical Advisory Group of the U.S. Department of Agriculture's Animal and Plant Health Inspection Service, publication of an environmental assessment in the Federal Register, and now a biological assessment reviewed by the U.S. Fish and Wildlife Service. If more information is needed, an environmental impact statement is made. Once the information in these assessments is sufficient and no harm is anticipated, then Animal and Plant Health Inspection Service issues a "finding of no significant impact" (FONSI). Once that finding has been issued, the Plant Protection and Quarantine Unit of Animal and Plant Health Inspection Service issues the permits required for interstate movement. This process has been established to provide compliance with the National Environmental Policy Act, the Endangered Species Act, and the Plant Protection Act. Furthermore, because federally listed threatened native thistles occur in both the west and upper Midwest (Zedler et al. 1983; Turner \& Herr 1996; Bevill et al. 1999; Herr 2000), ecosystem-specific risk could be taken into consideration in the Plant Protection and Quarantine issuance of interstate transport permits. This restricts the movement of any insect for which there is evidence suggesting potential for nontarget ecological effects within the recipient ecoregion.

Fourth, the host-specificity studies were not adequate to predict the magnitude of actual use of native thistles by L. planus in the field. As a result of host-specificity studies, both Zwölfer et al. (1971) and McClay (1990) ex- 
pected that stronger adult preference for Canada thistle, better larval performance on it, and the relatively low densities of native thistle would prevent significant use of the native plants by L. planus. This expectation represents the normative paradigm in contemporary biological control. Because preference and performance measure host acceptance and development by an insect, these parameters are expected to predict potential effects on a host (e.g., Zwölfer \& Harris 1984; Blossey et al. 1994; Marohasy 1996; MacFadyen 1998 . Our data challenge this expectation. Adult host preference and larval performance did not predict the effect of L. planus on seed production of Tracy's thistle. Ecological risk was underestimated seriously by these tests.

Furthermore, our data also challenge the predictiveness of some host traits used to anticipate host plants and effects under new field conditions. For example, flower-head size, considered an important character restricting potential host use by L. planus (Zwölfer 1964; McClay 1990), was not a sufficient predictor of acceptance or amount of use by L. planus in this study. The mature flowering heads of Tracy's thistle are relatively large: most are 4-6 cm high (range, 4-7 cm) and 2.5-2.8 $\mathrm{cm}$ wide, or two to six times larger than those of Canada thistle (1.5-2.0 cm long, 1.0-1.5 cm wide) (Bare 1979; Lym \& Christianson 1996). Clearly, the developing flower heads of this larger-headed native thistle were within the acceptable, successful size range for L. planus.

Fifth, our study indicates that ecological costs are associated with distributing L. planus and that the deliberate redistribution of $L$. planus entails a high risk-to-benefit ratio. Our data suggest that the deliberate spread of $L$. planus should stop and that compelling evidence should be required that no other risks exist for rare species before releases are restarted. To protect our native flora, similar restraint should also be considered for other biological control insects for which data on potential ecological effects are dated or incomplete. For example, the majority of exotic insects currently used for the control of thistles were introduced relatively early in the history of biological control efforts (Schröder 1980; Julien \& Griffiths 1998). No quantitative assessments of their potential threat to populations of rare or localized native North American Cirsium species were required or made (Schröder 1980). Given our results, assessment of potential nontarget effects of these species is needed.

More generally, our results argue for a renewed discussion of the deliberate introduction of exotic insects for the biological control of exotic weeds in natural areas. Current practices involving such introductions of exotic insects into nature reserves and national parks rely on incomplete assessments of ecological risk. In neither this case nor the case of Rhinocyllus conicus, both of which were discovered serendipitously rather than through systematic monitoring, did the main criterion for ecological risk assessment-host specificity-pre- dict the magnitude of ecological effects on secondarily acceptable native plants. We conclude that this case provides additional evidence that the ecological risks to native species of deliberate augmentation of the natural enemy complex with exotic species can be greater than expected.

\section{Acknowledgments}

We sincerely thank G. Austin, D. Fritts, D. Kazmer, D. Kendall, E. Lane, J. Michels, and K. Mowrer for information on biological control releases on Canada thistle in Colorado and the United States; A. Arnett, K. Bradley, A. Paradis, T. Rand, and L. Young for important suggestions on earlier drafts of the manuscript; R. Otley for help in the field; G. Balogh for identification of the moths in thistle flower heads; and, A. Konstantinov of the Natural History Museum, Washington, D.C., for providing identified European samples of three species of $L a$ rinus. Research on thistle-insect interactions (S.M.L.) was supported in part by grants from the Katherine Ordway and Rodney Johnson Stewardship Funds of The Nature Conservancy, The National Science Foundation (DEB92-21065, DEB9616210), and the University of Nebraska Research Council. Research on weevil systematics (C.W.O.B.) was supported in part by grants from the U.S. Department of Agriculture (FLAX 97007, CSREES, and NBCI / APHIS, 98-1001-0209-CA).

\section{Literature Cited}

Alonso-Zarazaga, M. A., and C. H. C. Lyal. 1999. A world catalogue of families and genera of Curculionoidea (excepting Scolytidae and Platypodidae). Entomopraxis, Barcelona.

Amor, R. L. 1975. Seedling establishment and vegetative spread of Cirsium arvense (L.) Scop. in Victoria, Australia. Weed Research 15:407-411.

Anonymous. 1999. Wyoming cooperative agricultural pest survey-1999. Cooperative Agricultural Pest Survey, Laramie, Wyoming.

Bailey, K. L., S. M. Boyetchko, J. Derby, W. Hall, K. Sawchyn, T. Nelson, and D. R. Johnson. 2000. Evaluation of fungal and bacterial agents for biological control of Canada thistle. Pages 203-208 in N. R. Spencer, editor. Proceedings of the tenth international symposium on biological control of weeds. U.S. Agricultural Research Service, Sydney, Montana.

Bare, J. E. 1979. Wildflowers and weeds of Kansas. Regents Press, Kansas, Lawrence.

Bevill, R. L., S. M. Louda, and L. M. Stanforth. 1999. Protection from natural enemies in managing rare plant species. Conservation Biology 13:1323-1331.

Blossey, B., D. Schroeder, S. D. Hight, and R. A. Malecki. 1994. Host specificity and environmental impact of the weevil Hylobius transversovittatus, a biological control agent of purple loosestrife (Lythrum salicaria). Weed Science 42:128-133.

Boldt, P. E. 1997. Response of a Rhinocyllus researcher. Biocontrol News and Information 18:100N. 
Center, T. D., J. H. FrankF. A. Dray Jr. 1995. Biological invasions: Stemming the tide in Florida. Florida Entomologist 78:45-55.

Cooperative Agricultural Pest Survey (CAPS). 2001. National agricultural pest information system. CAPS, Washington, D.C. Online at http://www.ceris.purdue.edu (accessed April 11, 2001).

Delfosse, E. S. 2000. Biological control: Important tool for managing invasive species. Agricultural Research 48:2.

Donald, W. W. 1994. The biology of Canada thistle (Cirsium arvense). Review of Weed Science 6:77-101.

Follett, P. A., and J. J. Duan, editors. 1999. Nontarget ecological effects of biological control. Kluwer Academic, Boston.

Forsyth, S. F., and A. K. Watson. 1985. Stress inflicted by organisms on Canada thistle. Pages 425-431 in E. S. Delfosse, editor. Proceedings of the sixth international symposium on biological control of weeds. Agriculture Canada, Ottawa.

Goeden, R. D., and D. W. Ricker. 1986a. Phytophagous insect faunas of two introduced Cirsium thistles, C. ochrocentrum and C. vulgare, in southern California. Annals of the Entomological Society of America 79:945-952.

Goeden, R. D., and D. W. Ricker. 1986b. Phytophagous insect faunas of the two most common native Cirsium thistles, C. californicum and C. proteanum, in southern California. Annals of the Entomological Society of America 79:953-962.

Goeden, R. D., and D. W. Ricker. 1987a. Phytophagous insect faunas of native Cirsium thistles, C. mohavense, C. neomexicanum, and C. nidulum, in the Mojave Desert of southern California. Annals of the Entomological Society of America 80:161-175.

Goeden, R. D., and D. W. Ricker. 1987b. Phytophagous insect faunas of the native thistles, Cirsium brevistylum, Cirsium congdonii, Cirsium occidentale, and Cirsium tioganum in southern California. Annals of the Entomological Society of America 80:152-160.

Haber, E. 1997. Invasive exotic plants of Canada. Fact sheet No. 8. National Botanical Services, Ottawa. Online at http://infoweb.magi.com/ ehaber/facthstl.html (accessed November 2000).

Harrington, H. D. 1964. Manual of the plants of Colorado. 2nd edition. Sage Books, Chicago.

Harris, P., and P. McEvoy. 1995. The predictability of insect host plant utilization from feeding tests and suggested improvements for screening weed biocontrol agents. Pages 118-137 in E. S. Delfosse and R. R. Scott, editors. Proceedings of the eighth international symposium on biological control of weeds. Commonwealth Scientific and Industrial Research Organization, Melbourne, Australia.

Herr, J. C. 2000. Evaluating non-target effects: the thistle story. Pages 12-17 in M. S. Hoddle, editor. Proceedings of the California conference on biological control. II. Entomology Department, University of California, Riverside.

Hoffmann, A. 1954. Faune de France. 59, Coleopteres Curculionides. Part 2. P. Lechevalier, Paris.

IPMnet News. 1995. Consortium for International Crop Protection. Integrated Plant Protection Center, Oregon State University, Corvallis. Online at http://ipmwww.ncsu.
edu/cicp/IPMnet_NEWS/news19.html (accessed August 23, 2001).

Julien, M. H., and M. W. Griffiths, editors. 1998. Biological control of weeds: A world catalogue of agents and their target weeds. 4th edition. CAB International, Wallingford, United Kingdom.

Kartesz, J. T. 1998. Asteraceae: Biota of North America program. Bioinformatics Working Group, Texas A \& M University, College Station. Online at http://www.csdl.tamu. edu/FLORA/bonapfams/bonxxast.htm (accessed September 15, 1999).

Louda, S. M. 1998a. Ecology of interactions needed in biological control practice and policy. Bulletin of the British Ecological Society 29:8-11.

Louda, S. M. 1998b. Population growth of Rhinocyllus conicus (Coleoptera: Curculionidae) on two species of native thistles in prairie. Environmental Entomology 27:834-841.

Louda, S. M. 1999. Negative ecological effects of the musk thistle biocontrol agent, Rhinocyllus conicus Fröl. Pages 215243 in P. A. Follet and J. J. Duan, editors. Nontarget effects of biological control. Kluwer Academic Publishers, Boston.

Louda, S. M. 2000. Rhinocyllus conicus: Insights to improve predictability and minimize risk of biological control of weeds. Pages 187-193 in N. R. Spencer, editor. Biological control of weeds. Proceedings of the tenth international symposium on biological control of weeds. U.S. Agricultural Research Service, Sydney, Montana.

Louda, S. M., and A. E. Arnett. 2000. Predicting non-target ecological effects of biological control agents: Evidence from Rhinocyllus conicus. Pages 551-567 in N. R. Spencer, editor. Biological control of weeds. Proceedings of the tenth international Symposium on Biological control of weeds. U.S. Agricultural Research Service, Sydney, Montana.

Louda, S. M., and M. A. Potvin. 1995. Effect of inflorescencefeeding insects in the demography and lifetime fitness of a native plant. Ecology 76:229-245.

Louda, S. M., M. A. Potvin, and S. K. Collinge. 1990. Predispersal seed predation, postdispersal seed predation and competition in the recruitment of seedlings of a native thistle in sandhills prairie. American Midland Naturalist 124:105-113.

Louda, S. M., M. A. Potvin, and S. K. Collinge. 1992. Predispersal seed predation in the limitation of native thistle. Pages 30-32 in S. B. J. Menken, J. H. Visser, and P. Harrewijn, editors. Insect-plant relationships. Kluwer Academic, Dordrecht, The Netherlands.

Louda, S. M., D. Kendall, J. Connor, and D. Simberloff. 1997. Ecological effects of an insect introduced for the biological control of weeds. Science 277:1088-1090.

Louda, S. M., D. Simberloff, G. Boettner, J. Connor, D. Kendall, and A. E. Arnett. 1998. Insights from data on the nontarget effects of the flowerhead weevil. Biocontrol News and Information 19:70N-71N.

Lym, R. G., and K. M. Christianson. 1996. The thistles of North Dakota. W-1120 edition. North Dakota State University Extension Service, Fargo.

MacFadyen, R. E. 1998. Biological control of weeds. Annual Review of Entomology 43:369-393. 
Malecki, R., and B. Blossey. 1994. Insect biological weed control: An important and underutilized management tool for maintaining native plant communities threatened by exotic plant introductions. Transactions of the North American Wildlife and Natural Resource Conference 59:400-404.

Marohasy, J. 1996. Host shifts in biological weed control: Real problems, semantic difficulties or poor science? International Journal of Pest Management 42:71-75.

McClay, A. S. 1990. The potential of Larinus planus (Coleoptera: Curculionidae), an accidentally introduced insect in North America, for biological control of Cirsium arvense. Pages 173-179 in E. S. Delfosse, editor. Proceedings of the seventh international symposium on the biological control of weeds. Instituto Sperimentale per la Patologia Vegetale, Rome.

McEvoy, P. B. 1996. Host specificity and biological pest control. BioScience 46:410-415.

Moore, R. J. 1975. The biology of Canadian weeds. 13. Cirsium arvense (L.) Scop. Canadian Journal of Plant Science 55:1033-1048.

National Invasive Species Council 2000. Meeting the invasive species challenge. Draft management plan. National Invasive Species Council, Washington, D.C.

National Park Service. 1999. Press release: Badlands National Park uses biological control for canada thistle. Badlands National Park, Rapid City, South Dakota. Online at http://www.nps.gov/badl/press/pr8-25-99.htm (accessed April 4, 2001).

O'Brien, C. W., and G. J. Wibmer. 1982. Annotated checklist of the weevils (Curculionidae sensu lato) of North America, Central America, and the West Indies (Coleoptera: Curculionoidea). Number 34. Memoirs of the American Entomological Institute, Ann Arbor, Michigan.

Office of Technology Assessment 1993. Harmful non-indigenous species in the United States. OTA-F-565. U.S. Government Printing Office, Washington, D.C.

Office of Technology Assessment 1995. Biologically based technologies for pest control. OTA-ENV-636. Government Printing Office, Washington D.C.

Pemberton, R. W. 2000. Predictable risk to native plants in weed biological control. Oecologia (Berlin). 125:489-494.

Randall, J. M. 1993. Exotic weeds in North American and Hawaiian natural areas: The Nature Conservancy's plan of attack. Pages 159-172 in B. N. McKnight, editor. Biological pollution: the control and impact of invasive exotic species. Indiana Academy of Science, Indianapolis.

Rees, N. E. 1977. Impact of Rhinocyllus conicus on thistles in southwestern Montana. Environmental Entomology 6:839-842.

Rice, R.D. Roddy. 1998. Canada thistle control by insects. Technical advances: Natural resources year in review-1996. Available from http://www2.nature.nps.gov/upbs/yrrvw96/chapter7/tthistle.htm (accessed April 4, 2001).

Schröder, D. 1980. The biological control of thistles. Biocontrol News and Information 1:10-26.

Simberloff, D., and P. Stiling. 1996. How risky is biological control? Ecology 77:1965-1974.

Stiling, P., and D. Simberloff. 1999. The frequency and strength of non-target effects of invertebrate biological control agents. Pages 31-44 in P. A. Follett and J. J. Duan, editors. Nontarget effects of biological control. Kluwer Academic, Dordrecht, The Netherlands.

Straw, N. A. 1989. The timing of oviposition and larval growth by two tephritid fly species in relation to host-plant development. Ecological Entomology 14:443-454.

Strong, D. R., and R. W. Pemberton. 2000. Biological control of invading species: Risk and reform. Science 288:196-197.

Turner, C. E., and J. C. Herr. 1996. Impact of Rhinocyllus conicus on a non-target, rare, native thistle (Cirsium fontinale) in California. Pages 103 in V. C. Moran and J. H. Hoffman, editors. Proceedings of the ninth international symposium on biological control of weeds. University of Cape Town, Stellenbosch, South Africa.

Turner, C. E., R. W. Pemberton, and S. S. Rosenthal. 1987. Host utilization of native Cirsium thistles (Asteraceae) by the introduced weevil Rhinocyllus conicus (Coleoptera: Curculionidae) in California. Environmental Entomology 16:111-115.

Van Driesche, R. G. 1994. Biological control for the control of environmental pests. Florida Entomologist 77:20-33.

Volovnik, S. V. 1996. Distribution and ecology of some species of Cleoninae (Coleoptera, Curculionidae). III. Genus Larinus Germ. Entomological Review 75:10-19.

Wajnberg, E., J. K. Scott, and P. C. Quimby, editors. 2001. Evaluating indirect ecological effects of biological control. CABI, Wallingford, United Kingdom.

Weber, W. A. 1987. Colorado flora: Western slope. Colorado Associated University Press, Boulder.

Wheeler, A. G., and D. R. Whitehead. 1985. Larinus planus (F.) in North America (Coleoptera: Curculionidae: Cleoninae) and comments on biological control of Canada thistle. Proceedings of the Entomological Society of Washington 87:751-758.

White, J. C. 1972. A European weevil, Larinus carlinae Oliver, collected in Maryland. Cooperative Economic Insect Report 22:418.

Zedler, P. H., K. Guehlstorff, C. Scheidlinger, and C. R. Gautier. 1983. The population ecology of a dune thistle, Cirsium rhothophyilum (Asteraceae). American Journal of Botany 70:1516-1527.

Zimmerman, K. 1997. Annual narrative report for Wyoming: Biological control of weeds. Wyoming Department of Agriculture, Laramie, Wyoming. Online at http://w3.uwyo. edu/ caps/annual/97AnRpt.htm\# Toc4020 (accessed April 4, 2001).

Zwölfer, H. 1964. Weed projects for Canada. Progress report no. 10: Larinus and Rhinocyllus. Commonwealth Institute of Biological Control, European Station, Delemont, Switzerland.

Zwölfer, H., and P. Harris. 1984. Biology and host specificity of Rhinocyllus conicus (Froel.) (Col., Curculionidae), a successful agent for biocontrol of the thistle, Carduus nutans L. Zeitschrift der Angewandte Entomologie 97:36-62.

Zwölfer, H., K. E. Frick, and L. A. Andres. 1971. A study of the host plant relationships of European members of the genus Larinus (Col.: Curculionidae). Technical bulletin 14. Commonwealth Institute of Biological Control, European Station, Delemont, Switzerland. 